\begin{tabular}{|c|c|c|c|}
\hline \multirow{2}{*}{$\begin{array}{c}\text { LARUS } \\
\text { Hrvatska akademija }\end{array}$} & 54 & $45-51$ str. & Zagreb 2019 \\
\cline { 2 - 4 } znanosti i umjetnosti & $(2019)$ & \multicolumn{3}{|c|}{\begin{tabular}{c} 
Primljeno 28.6.2019. \\
\cline { 2 - 4 }
\end{tabular}} & \multicolumn{3}{|c|}{ Prihvaćeno na sjednici Razreda za prirodne znanosti HAZU 21.11.2019. } \\
\hline
\end{tabular}

UDK 598.281/.296(497.5)

Original scientific paper Izvorni znanstveni članak DOI: https://dx.doi.org/10.21857/yq32oh4dw9

\title{
WITHIN-CLUTCH VARIATION IN SIZE AND SHAPE OF THE GREAT TIT Parus major EGGS
}

\section{Varijacije veličine i oblika jaja u gnijezdu velike sjenice Parus major \\ ZDRAVKO DOLENEC}

Mokrice 132, HR-49243 Oroslavje, CROATIA

\begin{abstract}
Ornithological studies on the egg characteristics of birds are important for understanding many components of their life histories. Over the past year (2019), I have been studying egg dimensions of Great Tit Parus major in a deciduous forest in Mokrice and Krušljevo Selo area, in north-western Croatia. This species is secondary hole-nesting passerine and all studied Great Tits bred in nestboxes. The effect of laying order (or laying sequence) on egg dimensions was analysed in clutches with 11 eggs (the modal clutch size in research area in study period) and only first clutches included. Average egg length, egg breadth, egg volume and elongation index (egg shape) of 110 eggs (10 clutches) was 17.35 $\mathrm{mm}, 13.47 \mathrm{~mm}, 1609.64 \mathrm{~mm}^{3}$ and 1.29 , respectively. In this study, there was no general trend of increasing or decreasing length, breadth and egg volume (egg size) in relation to the laying order (all $p>0.05$ ). However, a negative correlation between egg shape and laying sequence was significant.
\end{abstract}

Keywords: egg dimensions, egg shape, laying order, Great Tit, Parus major

e-mail: zdravko.dolenec@biol.pmf.hr 


\section{INTRODUCTION}

Ornithological studies on the egg characteristics of birds are important for understanding many components of their life histories. During the past few decades, numerous studies on the reproduction of birds in Europe have focused on several regions (e.g. Bourgault et al. 2007, DA Silva et al. 2012), whereas birds in Southeast Europe have been less investigated (e.g. Dolenec 2011, Ćıкović et al. 2014).

This study describes dimensions (length, breadth, and volume) of eggs and elongation index (egg shape) of the Great Tit Parus major in relation to laying order (laying sequence). This species is a small socially monogamous hole-nesting passerine which breeds in natural and artificial holes - nestboxes (CRAMP 1998). The Great Tit is a common bird species in north-western Croatia (Dolenec 2003, KIRIN et al. 2011) and both parents feed the young (one or two broods annually). Generally, in birds, egg volume (or egg mass) may fluctuate with laying order in several ways: (1) egg volume (or egg mass) decreases with position in the laying order (e.g. Невв 1994, Boileau \& Hoede 2009), (2) egg volume (or egg mass) increases with position in the laying order (e.g. HAFTORN 1986, Song et al. 2016), (3) laying order had no impact on egg volume (or egg mass) (e.g. Nilsson \& Svensson 1993, Fernandez \& Reboreda 2008). According to some ornithologists (e.g. Howe 1976, Stagsvold et al. 1984), decrease in egg size with laying order enhances the impact of asynchronous hatching ("brood reduction strategy") whereas the contrary trend ("brood survival strategy") would reduce the consequences in hatchling sizes caused by asynchrony. Asynchronous hatching is characterised by the incubation that starts before all the eggs have been laid (e.g. Magrath 1990). The aim of this study was to determine which breeding strategy the Great Tit uses in the area of north-western Croatia.

\section{MATERIAL AND METHODS}

I have studied egg dimensions and egg shape fluctuations within clutches in relation to laying order of the Great Tit. The study was conducted within the small natural deciduous forest (dominated by the pedunculate oak Quercus robur and European hornbeam Carpinus betulus) in north-western Croatia (Mokrice and Krušljevo Selo area; $45^{\circ} 58^{\prime}-46^{\circ} 00^{\prime} \mathrm{N}, 15^{\circ} 51^{\prime}-15^{\circ} 54^{\prime} \mathrm{E}$ ), in 2019 . Within-clutch fluctuations were calculated from 110 eggs in 10 clutches. The effect of laying order on egg dimensions was analysed only on clutches with 11 eggs (the modal clutch size in research area), and only first clutches included. The laying order was established by numerating each egg on the laying day with a waterproof marking pen. Only eggs from completed clutches were used to characterise egg dimensions and egg shape. Each egg was numbered with a felt-tipped, waterproof marking pen on the day it was laid to establish the laying order. One egg 
was laid per day. All studied Great Tits bred in nestboxes. The Great Tit readily accepts nestboxes for reproduction (e.g. Mänd et al. 2005, Dolenec 2019). The dimensions of the nestboxes were $12 \times 12 \times 23 \mathrm{~cm}$, the entrance hole had a $3.2 \mathrm{~cm}$ diameter and internal depth under the entrance was ca. $16 \mathrm{~cm}$. Nestboxes inspected with standardised protocols from the mid-March to mid-July and egg dimension was measured (sliding callipers) in relation to laying order (the nearest $0.01 \mathrm{~mm}$ ). All eggs were marked with a permanent marker. All measurements of eggs were performed by the author. Based on maximum breadth (B) and maximum length (L) of eggs, volume (V) was calculated applying Hoyт's (1979) formula, V = 0.51 $x \mathrm{~L} \times \mathrm{B}^{2}$ and egg shape (elongation index, EI) was calculated according to the formula: $\mathrm{EI}=\mathrm{L} / \mathrm{B}$. This method was used previously in numerous studies (e.g. Dolenec 1994, Zduniak \& Antczak 2003, Johnson et al. 2006, Dolenec et al. 2007)

Data were analysed using SPSS version 17.0 for Windows. Relationship between egg traits and laying sequence were shown with Pearson's correlation test. Significance was set at $\mathrm{p}<0.05$ for all statistical tests.

\section{RESULTS AND DISCUSSION}

Average length, breadth, volume and elongation index (egg shape) of 110 eggs (10 clutches) were $17.35 \mathrm{~mm}$ (range $=16.05$ to $18.87 \mathrm{~mm}$ ), $13.47 \mathrm{~mm}$ (range $=12.54$ to $14.33 \mathrm{~mm}), 1609.64 \mathrm{~mm}^{3}\left(1309.64\right.$ to $\left.1882 \mathrm{~mm}^{3}\right)$ and $1.29($ range $=1.19$ to 1.41), respectively. Relationship between egg length and breadth was positive and significant $(\mathrm{r}=0.376, \mathrm{p}<0.001, \mathrm{n}=110)$. The positive correlation between the egg length and egg breadth in the Great Tit is similar to some other bird species (e.g. Enemar 1997, Dolenec 2006a). Results of this study illustrated no impact of laying order on within-clutch fluctuation in egg length $(r=-0.171, p=0.076$, $\mathrm{n}=110)$, egg breadth $(\mathrm{r}=0.041, \mathrm{p}=0.667, \mathrm{n}=110)$ and egg volume $(\mathrm{r}=-0.045$, $\mathrm{p}=0.641, \mathrm{n}=110$ ). According to values of egg volume in relation to the laying sequence this result does not support the "brood reduction strategy" or "brood survival strategy" in north-western Croatia. However, in China (You et al. 2009), the Great Tit, laying order was significantly positively correlated with egg size (result provided support for the "brood survival strategy"). In previous papers in Croatia, in other passerines, I documented the increase of egg size in relation to laying order for the Blackcap Sylvia atricapilla (Dolenec 2004) and Black Redstart Phoenicurus ochruros (Dolenec 2006b). However, in the Common Starling Sturnus vulgaris (Dolenec 2001), Barn Swallow Hirundo rustica (Dolenec 2002a), Tree Sparrow Passer montanus (Dolenec 2002b) and Nuthatch Sitta europaea (DoleNEC 2005) there were no correlations. Elongation index was negatively correlated with the laying order- slightly but statistically significant $(r=-0.195, p=0.041, n$ $=110$; Figure 1). Egg shape tended to decrease until the 11th egg. Results suggest that the last-laid eggs in the nest are more spherical than the first-laid eggs. Eggs with a more spherical shape have a smaller surface area in relation to the eggs 
with a more elliptical shape. A possible explanation could be that by applying this strategy, the females save calcium (eggshell) in the eggshells of the last-laid eggs (e.g. Ojanen et al. 1978, Gosler et al. 2005). Calcium is a crucial micronutrient in egg formation in the reproductive period (e.g. Perrins 1996, Tilgar et al. 2002). The eggshell contains about $94 \%$ calcium carbonate (MurAKAMI et al. 2007) and an important source of calcium for the Great Tit are small forest snails (e.g. Graveland 1990, Gosler 2006). According to Eeva \& Lehikoinen (1995), the total amount of calcium that a laying female contributes to complete her clutch is a function of clutch size and shell mass. Furthermore, round-shaped eggs compared to more elliptical ones are increasing the efficiency of incubation in larger clutches (e.g. Ojanen et al. 1978, Hutchinson 2000). Rounded eggs also take up less space than elliptical ones and are therefore covered better by the incubating female, which probably makes the incubation of large clutches more efficient.

For a better understanding of the breeding strategy of the Great Tit, further research is needed covering different altitude, latitude and habitat. According to BRISKIE \& SEALY (1990), variation in egg size has evolutionary significance only if it affects some measure of reproductive success.

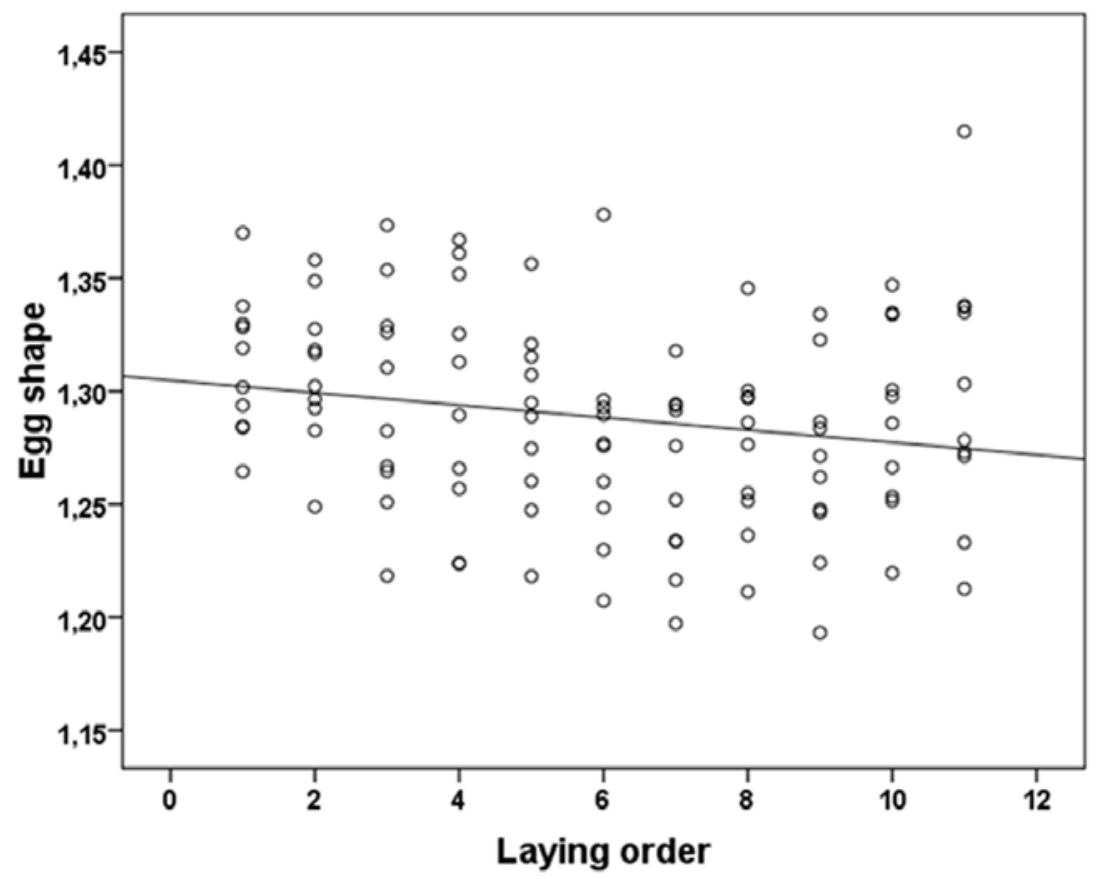

Figure 1. Relationship between egg shape (elongation index) and laying order of the Great Tit Parus major $(r=-0.195, \mathrm{p}=0.041, \mathrm{n}=110)$. Line indicates linear regression.

Slika 1. Odnos između oblika jaja (indeks izduženosti) i redoslijeda nesenja velike sjenice Parus major ( $r=-0.195, p=0.041, n=110$ ). Crta pokazuje linearnu regresiju. 


\section{References}

Boileau, N., Hoede, C. (2009): Variations in egg size in the Common Kestrel Falco tinnunculus. Alauda 77: 21-30.

Bourgault, P., Thomas, D. W., Blondel, J., Perret, P., Lambrechts, M. M. (2007): Between-population differences in egg composition in Blue Tits (Cyanistes caeruleus). Can. J. Zool. 85: 71-80.

BRISKIE, J. V., SEALY, S. G. (1990): Variation in size and shape of Least Flycatcher eggs. J. Field Ornithol. 61: 180-191.

Cramp, S. (1998): Complete Birds of Western Palaearctic's on CD-ROM. Oxford University Press, Oxford.

Ćiković, D., BARIšić, S., Tutiš, V., KRALJ, J. (2014): Nest site and nest-hole characteristics used by Great Spotted Woodpecker Dendrocopos major L. in Croatia. Pol. J. Ecol. 62: 349-360.

Da Silva, L. P., Alves, J., Da Silva, A. A., Ramos, J. A., Fonseca, C. (2012): Variation in the abundance and reproductive characteristics of Great Tits Parus major in forest and monoculture plantations. Acta Ornithol. 47: 147-155.

Dolenec, Z. (1994): Nest structure and egg-characteristics of the Blackcap (Sylvia atricapilla) in a region Croatia. Vogelwarte 37: 304-305.

Dolenec, Z. (2001): Correlations between egg characteristics and laying order in the starling (Sturnus vulgaris) in NW Croatia. Nat. Croat. 10: 11-17.

Dolenec, Z. (2002a): Breeding characteristics of the barn swallow (Hirundo rustica) in NW Croatia. Nat. Croat. 11: 439-445.

Dolenec, Z. (2002b): Intraclutch egg dimensions variation in the Tree Sparrow Passer montanus. Larus 48: 47-54.

Dolenec, Z. (2003): Qualitative structure of the community of nesting birds between 1971-2000 in the Mokrice rural area (NW Croatia). Nat. Croat. 12: 121-130.

Dolenec, Z. (2004): Relationship between laying order and egg dimensions in the Blackcap Sylvia atricapilla. Acta Ornithol. 39: 176-179.

Dolenec, Z. (2005): Clutch size, egg dimensions and breeding strategy in the Nuthatch Sitta europaea. Larus 49: 13-17.

Dolenec, Z. (2006a): Nest density, clutch size and egg dimensions of the Hooded Crow (Corvus corone cornix). Nat. Croat. 15: 231-235.

Dolenec, Z. (2006b): Egg dimensions variation in relation to the laying order in Black Redstart (Phoenicurus ochruros Gmelin, 1774) in NW Croatia. Belg. J. Zool. 136: 257-258.

Dolenec, Z. (2011): Some breeding traits of the pied wagtail (Motacilla alba) in NW Croatia. Nat. Croat. 20: 209-214.

Dolenec, Z. (2019): Nest-box occupancy by the Great Tit (Parus major) in young deciduous forest. Šumarski list 143 (7-8): 347-352. (In Croatian with English summary)

Dolenec, Z., Delić, A., Kralj, J., Dolenec, P. (2007): Variation in egg dimensions of the Tree Sparrow (Passer montanus L.) in north-western Croatia. Pol. J. Ecol. 55: 841-845. 
Eeva, T., Lehikoinen, E. (1995): Egg shell quality, clutch size and hatching success of the great tit (Parus major) and the pied flycatcher (Ficedula hypoleuca) in an air pollution gradient. Oecologia 102: 312-323.

Enemar, A. (1997): The egg size variation of the Treecreeper Certhia familiaris in southwestern Sweden. Ornis Svecica 7: 107-120.

Fernandez, G. J., Reboreda, J. C. (2009): Between and within clutch variation of egg size in Greater Rheas. Wilson J. Ornithol. 120: 674-682.

Graveland, J. (1990): Effect of acid precipitation on reproduction in birds. Experientia 46: $962-970$.

Gosler, A. G. (2006): Yet more ways to dress eggs. Br. Birds 99: 338-353.

Gosler, A. G., Higham, J. P., ReynoldS, S. J. (2005): Why are birds' eggs speckled? Ecol. Lett. 8: 1105-1113.

Haftorn, S. (1986): Clutch size, intraclutch egg size variation, and breeding strategy in the Goldcrest Regulus regulus. J. Orn. 127: 291-301.

Неeв, P. (1994): Intraclutch egg-mass variation and hatching asynchrony in the Jackdaw Corvus monedula. Ardea 82: 287-297.

Ноут, O. F. (1979): Practical methods of estimating volume and fresh weight of bird eggs. Auk 96: 73-77.

Howe, H. E. (1976): Egg size, hatching asynchrony, sex, and brood reduction in the Common Grackle. Ecology 57: 1195-1207.

Hutchinson, J. (2000): Three into two doesn't go: two-dimensional models of bird eggs, snail shells and plant roots. Biol. J. Linn. Soc. 70: 161-187.

Johnson, L. S., Ostlind, E., Jessica L. Brubaker, J. L., Balenger S. L., Johnson, B. G. P., Golden, H. (2006): Changes in egg size and clutch size with elevation in a Wyoming population of Mountain Bluebirds. Condor 108: 591-600.

Kirin, T., KralJ, J., Ćíović, D., Dolenec, Z. (2011): Habitat selection and similarity of the forest songbird communities in Medvednica and Žumberak - Samoborsko gorje nature parks. Šumarski list 135: 467-475.

Magrath, R. (1990): Hatching asynchrony in altricial birds. Biol. Rev. 65: 587-622.

Mänd, R., Tilgar, V., Lhmus, A., Leivitis, A. (2005): Providing nest boxes for hole-nestling birds - Does habitat matter? Biodivers. Conserv. 14: 1823-1840.

Murakami, F. S., Rodrigues, P. O., De Campos, C. M. T., Silva, M. A. S. (2007): Physicochemical study of $\mathrm{CaCO} 3$ from egg shells. Ciênc. Tecnol. Aliment. Campinas 27: 658-662.

Nilsson, J. Å., Svensson, E. (1993): Causes and consequences of egg mass variation between and within blue tit clutches. J. Zool. (Lond.) 230: 469-481.

OJanen, M., Orell, M.,VäIsänen, R. A. (1978): Egg and clutch sizes to four passerine species in northern Finland. Ornis Fennica 55: 60-68 .

Perrins, C. M. (1996): Eggs, egg formation and the timing of breeding. Ibis 138: 2-15.

Slagsvold, T., Sandvik, J., Rofstad, G., Lorentsen, O., Husby, M. (1984): On the adaptive value of intra-clutch egg-size variation in birds. Auk 10: 685-697. 
Song, S., Chen, J., Jiang, B., Liv, N. (2016): Variation in egg and clutch size of the Black Redstart (Phoenicurus ochruros) at the northeastern edge of the Qinghai-Tibetan Plateau. Avian Res. 7:20.

Tilgar, V., MäND, R., MäGI, M. (2002): Calcium shortage as a constraint on reproduction in Great Tit Parus major: a field experiment. J. Avian Biol. 33: 407-413.

Zduniak, P., ANTcZaK, M. (2003): Repeatability and within-clutch variation in egg dimensions in a Hooded Crow Corvus corone cornix population. Biol. Lett. 40: 37-42.

You, Y., Feng, J., Wang, H., WAng, J., Dong, C., Su, X., Sun, H., Gao, W. (2009): Variation in egg size and nestling growth rate in relation to clutch size and laying sequence in great tits Parus major. Prog. Nat. Sci. 19: 427-433.

\section{SAŽETAK}

Oološka istraživanja vezana uz dimenzije jaja ptičjih vrsta, odnosno njihovih populacija, važna su sastavnica u potrazi za razumijevanjem zakonitosti razmnožavanja u ornitologiji. U ovome su radu istraživane dimenzije jaja te njihov oblik u odnosu na redoslijed nesenja kod velike sjenice Parus major, sekundarne dupljašice na području sjeverozapadne Hrvatske u sezoni gniježđenja 2019. godine. Analizirana su jaja samo prvog legla kojih se polog nalazio u umjetnim dupljama (škrinjicama) dok se podaci iz prirodnih duplji nisu uzorkovali. Analizirana su samo gnijezda sa 11 jaja (modalna vrijednost na području istraživanja) budući da jednak polog zahtjeva približno jednako energetsko ulaganje ženki. Dosadašnji radovi dokumentiraju heterogenost s obzirom na veličinu jaja i njihov oblik u odnosu na tijek polaganja; neki autori spominju postupno povećanje jajeta od prvog snesenog do posljednjeg, drugi postupno smanjenje, a u trećih autora nema povezanosti. S obzirom na veličinu jaja redoslijedom njihova polaganja razlikujemo dvije reproduktivne strategije kod ptica: a) „strategija preživljavanja mladunaca u gnijezdu“ i b) „strategija redukcije mladih ptica u gnijezdu“. Prva se strategija odnosi na gnijezda u kojima su jaja redoslijedom nesenja sve veća, pa će se iz posljednje snesenog jajeta izvaljati najveći čučavac i neće ga pogoditi asinkrona inkubacija pod kojom se podrazumijeva početak inkubacije prije nego je sneseno posljednje jaje. Suprotno je kod druge strategije, posljednji ptić, izvaljan dan kasnije je najmanji pa ako dođe do pomanjkanja hrane roditelji će ga prestati hraniti. U ovom istraživanju nije bilo značajne promjene dimenzija jaja (duljina, širina i volumen) s obzirom na redoslijed nesenja što znači da rezultati ne podržavaju niti jednu od dvije spomenute strategije. Međutim, oblik jaja se mijenjao redoslijedom nesenja. Posljednja jaja su bila okruglija nego prva što znači da imaju manju površinu u odnosu na volumen. Time ženka troši manje kalcija za ljuske posljednjih jaja. Okruglija jaja zauzimaju manje prostora pa su bolje pokrivena tijekom inkubacije. 